
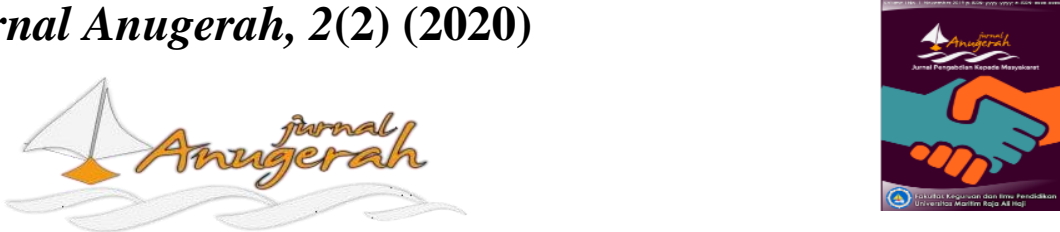

e-ISSN 2715-8179

https://ojs.umrah.ac.id/index.php/anugerah

\title{
Sosialisasi E-book Berbasis Smartphone pada Materi Polinomial di Kelas XI SMA Negeri 4 Tanjungpinang
}

\author{
Linda Rosmery T., Nur Asma Riani Siregar*, Susanti \\ Program Studi Pendidikan Matematika \\ Universitas Maritim Raja Ali Haji, Tanjungpinang, Kepulauan Riau 29214, Indonesia \\ *e-mail korespondensi: nur_asmariani@umrah.ac.id
}

Pengiriman: 13 September 2020; Diterima: 14 Oktober 2020; Publikasi: 30 November 2020

DOI: https://doi.org/10.31629/anugerah.v2i2.2521

\begin{abstract}
Abstrak
Sistem pendidikan pada Revolusi 4.0 menuntut pembelajaran secara modern dengan pemanfaatan kemajuan teknologi informasi dan komunikasi. Salah satu pemanfaatan teknologi di era digital dalam bidang pendidikan adalah pengembangan bahan ajar e-book berbasis smartphone. Hasil studi literatur pengabdian terdahulu menunjukkan bahwa penggunaan e-book dapat meningkatkan motivasi belajar siswa. Karena itu, dilaksanakan kegiatan pengabdian kepada masyarakat di SMA Negeri 4 Tanjungpinang dengan objek sasaran kegiatan 20 orang siswa kelas XI. Tujuan kegiatan ini adalah untuk memperkenalkan e-book berbasis smartphone pada materi polinomial dalam kegiatan pembelajaran matematika untuk menambah minat belajar siswa. Kegiatan pengabdian masyarat dilaksanakan dengan metode pendekatan sosialisasi dengan menggunakan aplikasi Zoom Meeting melalui tiga tahap kegiatan yaitu pemaparan cara penggunaan $e$-book, penggunaan $e$-book berbasis smartphone dalam pembelajaran dan evaluasi pelaksanaan kegiatan. Hasil evaluasi menunjukkan bahwa penggunaan e-book berbasis smartphone pada kegiatan pembelajaran dapat menambah minat belajar siswa.
\end{abstract}

Kata kunci: e-book; e-book berbasis smartphone

\section{Abstract}

One of the uses of technology in the digital era in education is the development of teaching materials based on smartphones e-books. The results of previous community service show that the use of interactive e-books can increase student learning motivation. Therefore, we carried out a community service activity at SMA Negeri 4 Tanjungpinag, with 20 students of grade 11 as the object of activity. The purpose of community service activities is to introduce smartphone-based e-books on polynomial material in classroom learning activities to increase student interest in learning. This activitiy used the socialization approach method with the Zoom Meeting application through three stages of activities, namely explaining how to use e-books, practicing using smartphone-based e-books in learning, and evaluating the implementation of activities. The results show that smartphone-based e-books in learning activities increase students' interest in learning.

Keywords: e-books; smartphone-based e-books

\section{Pendahuluan}

Penerapan teknologi memberi kemudahan diberbagai aspek pendidikan, seperti aspek pendidik, siswa, sistem pendidikan, dan sistem sarana dan prasaranapendidikan. Alat teknologi informasi dan komunikasi (TIK) dapat berupa laptop, komputer, handpone, smartphone, android, maupun alat perantaranya untuk mendukung 
JURNAL ANUGERAH, November 2020; Vol 2(2): 75 - 82

e-ISSN 2715-8179

alat teknologi seperti infokus, speaker, dan lain-lainnya. Dwiyogo (2014) menyatakan bahwa teknologi modern bersifat praktis untuk digunakan dalam proses pembelajaran, sehingga siswa dapat merasakan kemudahannya untuk belajar secara praktis,efisien, dan fleksibel.

Penggunaan teknologi adalah tuntutan dari era revolusi industri 4.0. Popkova, Ragulina, dan Bogoviz (2019) menyatakan bahwa revolusi industri 4.0 merupakan perkembangan teknologi yaitu Internet of Things (IoT). Dengan demikian sangat berpengaruh terhadap pendidikan, sehingga Suartama, Setyosari, Sulthoni, dan Ulfa (2019) menyebutkan pendidikan pada era 4.0. menuntut pembelajaran secara modern dengan menggunakan alat teknologi. Tetapi kenyataannya dilapangan, proses pembelajaran belum menggunakan teknologi secara optimal. Selain itu, proses pembelajaran yang sedang berlangsung sekarang masih menggunakan metode konvensional atau ceramah dan belum memanfaatkan alat teknologi dalam pembelajaran sehingga menimbulkan kejenuhan dan tidak optimalnya pemahaman materi yang dijelaskan. Hal ini sesuai pernyataan Nasution, Nasution, dan Hidayat ( 2018) bahwa siswa mengalami kejenuhan karena metode mengajar yang digunakan adalah ceramah dan belum memanfaatkan media pembelajaran sehingga siswa belum memahami materi yang disampaikan secara optimal. Agar proses pembelajaran berjalan dengan lancar, maka teknologi dibutuhkan oleh guru karena teknologi mampu menyita perhatian siswa sehingga siswa fokus dengan pembelajarannya dan memahami yang guru sampaikan.

Pemanfaatan teknologi pada bidang pembelajaran dapat berupa pengembangan $e$-book sebagai bahan ajar atau media pembelajaran. Alwan (2018) menjelaskan bahwa e-book adalah objek digital yang berisi tulisan atau konten-konten lainnya, seperti gambar, video, animasi, disertai dengan fitur-fitur yang telah disediakan oleh elektronik. Pemilihan $e$-book dapat dikatakan tepat dalam pembelajaran, karena pengguna $e$ book dapat mengaksesnya kapan saja dan dimana saja secara online melalui perangkat elektronik, seperti laptop atau pc, tablet dan smartphone. Adanya e-book ini dapat memberikan kemudahan bagi siswa dalam melakukan kegiatan belajar.

Salah satu produk teknologi yang mendukung e-book adalah smartphone. Choi et al. (2015) mengungkapkan bahwa smartphone terdapat berbagai fungsi yang berbasis internet. Seperti, panggilan suara atau video, media sosial, gameatau permainan, dan lain-lainnya untuk berkomunikasi dengan nyaman dan cepat untuk memperoleh informasi. Nurhatmi, Rusdi, dan Kamid (2015) juga mengungkapkan bahwa smartphone menyediakan berbagai fasilitas aplikasi, sehingga disebut dengan smartphone multifungsi. Teknologi smartphone dapat digunakan oleh guru sebagai media pembelajaran untuk meningkatkan partisipasi dan motivasi siswa dalam kegiatan belajar (Baby, 2019).

E-book yang berbasis smartphone dapat disajikan secara interaktif. E-book terdiri dari teks, gambar, animasi, video, dan evaluasi yang disatukan dalam program dan tampilan yang menarik, sehingga siswa tidak bosan untuk memperhatikannya. Jazuli, Anggo, Rahim, dan Sahidin (2017) menyatakan bahwa terdapat link interaktif yang saling berhubungan dan memberikan efek pada slide selanjutnya. E-book berbasis smartphone memiliki komponen evaluasi yang dapat dikerjakan langsung pada aplikasi e-book. Hasil dari evaluasi dapat segera diketahui siswa setelah selesai mengerjakan soal evaluasi, sehingga siswa secara langsung dapat mengetahui pada soal yang mana saja ia berhasil atau gagal menjawab dengan benar. Hal ini menimbulkan efek positif yaitu siswa dapat melakukan evaluasi tingkat penguasaanya mandiri.

Salah satu materi pembelajaran matematika adalah materi polinomial pada kelas XI SMA. Materi polinomial terdapat tiga sub bab materi yang akan dipelajari oleh siswa yaitu fungsi polinomial, pembagian polinomial dan persamaan polinomial. Siswa dituntut untuk memahami ketiga sub bab tersebut dengan cara menghapal rumus dan perlu bimbangan dari guru. Seringkali siswa mengalami kesulitan untuk membedakan rumus mana yang akan digunakan untuk menyelesaikan soal polinomial yang diberikan.

Berdasarkan hasil studi lapangan, diperoleh informasi bahwa bahan ajar yang digunakan di SMA Negeri 4 Tanjungpinang masih berupa bahan ajar cetak dan belum mengoptimalkan penggunaan smartphone sebagai sarana belajar. Bahan ajar cetak ini ternyata belum berhasil menarik minat siswa di SMA Negeri 4 
Tanjungpinang untuk belajar aktif baik di dalam kelas maupun di luar kelas. Siswa menginginkan pembelajaran yang menyenangkan, unik dan menarik agar siswa lebih paham dan mengerti dalam proses belajar. Dalam hal ini, tidak tersedianya bahan ajar non cetak atau bahan ajar elektronik khususnya yang berbasis smartphone menjadi salah satu hal yang sangat disayangkan, mengingat semua siswa di SMA Negeri 4 Tanjungpinang memiliki perangkat Smartphone. Seyogianya keadaan tersebut dapat dimanfaatkan para guru dengan menjadikan Smartphone sebagai media pembelajaran di kelas maupun di luar kelas.

Selanjutnya, pengabdian masyarakat yang memanfaatkan teknologi dalam pengajaran memberikan hasil yang positif bagi guru dan siswa (Asikin, Nevrita \& Alpindo, 2019; Astuti \& Febrian, 2019). Pengabdian oleh Negara, Syaharuddin, Kurniawati, Mandailina, dan Santosa (2019) memanfaatkan media belajar berbasis smartphone android, memberikan hasil yang positif yakni pemanfaatan aplikasi android minat siswa dalam belajar matematika menjadi tinggi. Pengabdian oleh Rosiska (2019) memanfaatkan aplikasi virtual learning berbasis android dalam meningkatkan kualitas pembelajaran, memperoleh beberapa kesimpulan yaitu: (1) Pemanfaatan aplikasi android dalam membantu proses pembelajaran diluar sekolah mampu memberikan dampak efektivitas yang baik untuk menunjang penambahan ilmu dan pengetahuan; (2) Dengan adanya aplikasi berbasis android, maka proses pembelajaran dapat dilakukan dimana saja dan kapan saja; dan (3) Besarnya dampak yang diberikan dalam pemanfaatan aplikasi dari hasil evaluasi yaitu saat sebelum dilakukan sebesar $30 \%$ dan saat setelah dilakukan sebesar $70 \%$. Pengabdian masyarakat yang dilakukan oleh Sam'ani, Sutami, dan Qamaruzzaman (2019) tentang implementasi aplikasi pembelajaran untuk anak berbasis android menghasilkan kesimpulan positif yaitu para guru antusias untuk menggunakan aplikasi smartphone berbasis android dalam pembelajaran dan para siswa juga dapat lebih mengerti materi dan dengan mudahnya mereka menjawab berbagai pertanyaan yang diajukan.

Permasalahan yang telah dipaparkan dan hasil pengabdian tersebut di atas menjadi acuan bagi dosen UMRAH untuk melakukan pengabdian masyarakat. Tim dosen Pendidikan Matematika UMRAH tertarik untuk melakukan pengabdian masyarakat dengan judul "Sosialisasi E-book Berbasis Smartphone Pada Materi Polinomial di Kelas XI SMA Negeri 4 Tanjungpinang”. Tujuan dari kegiatan pengabdian masyarakat ini adalah untuk mensosialisasikan penggunakan e-book berbasis smartphone pada materi polinomial dalam kegiatan pembelajaran dikelas untuk menambah minat belajar siswa. Dengan adanya $e$-book ini diharapkan dapat memberikan kemudahan bagi siswa untuk mempelajari materi polinomial.

Pada kegiatan ini, siswa secara langsung dilibatkan dalam kegiatan pembelajaran yang memanfaatkan e-book berbasis smartphone sebagai media pembelajaran. Pembelajaran dilakukan secara virtual dengan menggunakan apikasi zoom meeting. Kegiatan seperti ini belum pernah dilakukan pada kegiatan pembelajaran matematika di kelas XI SMA Negeri 4 Tanjungpinang.

\section{Metode}

Kegiatan pengabdian masyarakat ini dilaksanakan di SMA Negeri 4 Tanjungpinang. Waktu pelaksanaan kegiatan pengabdian masyarakat dilakukan pada bulan agustus tahun ajaran 2020/2021. Sasaran kegiatan ini adalah seluruh siswa kelas XI IPA SMA Negeri 4 Tanjungpinang. Metode yang digunakan dalam kegiatan pelaksanaan pengabdian masyarakat adalah berupa pendekatan sosialisasi dalam bentuk implementasi $e$-book berbasis Smartphone di kelas XI SMA Negeri 4 Tanjungpinang yang dilakukan secara daring via zoom meeting.

E-book berbasis smartphone pada mataeri polynomial dikembangkan oleh tim PKM sebelum melaksanakan implementasi kegiatan. E-book yang dikembangkan didesain dengan menerapkan prinsip pengembangan media pembelajaran. Dilengkapi dengan komponen media pembelajaran seperti komponen tujuan, uraian materi dan evaluasi beserta umpan baliknya. Deskripsi e-book berbasis smartphone yang dikembangkan ditunjukkan oleh Gambar 1. 


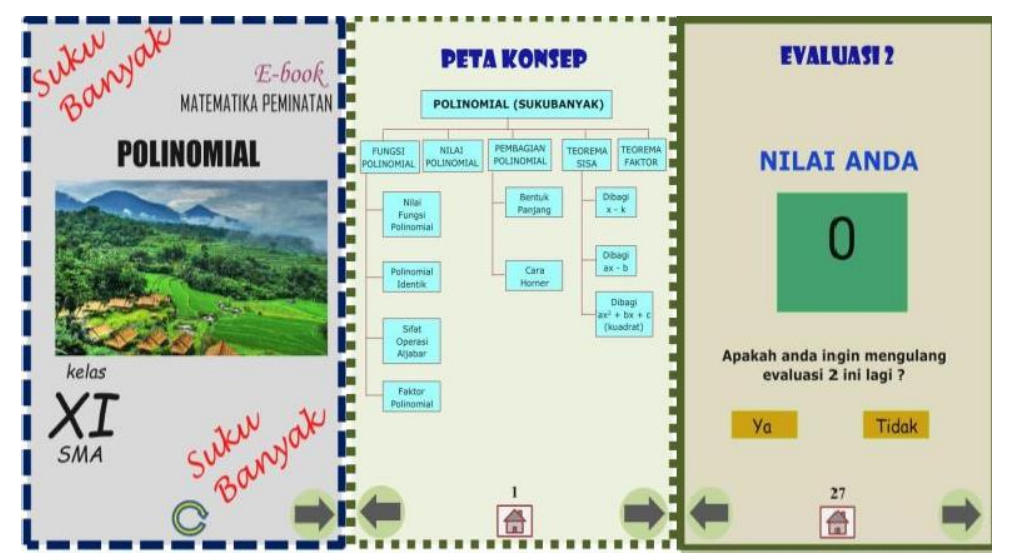

Gambar 1. Deskripsi e-book

Implementasi kegiatan PKM terdiri dari tiga tahap kegiatan yaitu, pemaparan penggunaan e-book berbasis smartphone, penggunaan $e$-book berbasis smartphone dalam kegiatan pembelajaran, dan evaluasi pelaksanaan kegiatan PKM menggunakan instrumen angket. Instrumen angket digunakan untuk mengumpulkan data respon peserta terhadap kegiatan implementasi PKM. Data respon peserta yang dikumpulkan terdiri dari tiga aspek penilaian yaitu: (1) aspek desain, (2) aspek usabilitas, dan (3) aspek manfaat. Adapun pernyataan yang bersesuaian dengan masing-masing aspek disajikan pada Tabel 1.

Tabel 1.

Sebaran Item Angket

\begin{tabular}{|c|c|c|}
\hline Aspek & Pernyataan & No. Item \\
\hline \multirow[t]{2}{*}{ Desain } & $\begin{array}{l}\text { E-book berbasis smartphone yang dikembangkan menarik, } \\
\text { kreatif dan inovatif }\end{array}$ & 1 \\
\hline & $\begin{array}{l}\text { Materi disajikan secara terstruktur dengan menggunakan } \\
\text { bahasa yang mudah dimengerti }\end{array}$ & 2 \\
\hline \multirow[t]{2}{*}{ Usabilitas } & $\begin{array}{l}\text { E-book berbasis smartphone yang dikembangkan mudah } \\
\text { digunakan }\end{array}$ & 3 \\
\hline & $\begin{array}{l}\text { E-book berbasis smartphone yang dikembangkan praktis } \\
\text { untuk dibawa dan digunakan setiap saat }\end{array}$ & 4 \\
\hline \multirow[t]{3}{*}{ Manfaat } & $\begin{array}{l}\text { Dengan adanya e-book berbasis smartphone, saya lebih } \\
\text { semangat untuk belajar }\end{array}$ & 5 \\
\hline & $\begin{array}{l}\text { E-book berbasis smartphone dapat membantu saya lebih } \\
\text { mudah memahami materi pelajaran }\end{array}$ & 6 \\
\hline & E-book yang dikembangkan efektif digunakan sebagai media & 7 \\
\hline
\end{tabular}




\begin{tabular}{lcc}
\hline Aspek & Pernyataan & No. Item \\
\hline pembelajaran pada materi polinomial & \\
\cline { 2 - 3 } & Dengan menggunakan $e$-book berbasis smartphone, saya & \\
dapat dengan segera mengetahui hasil latihan yang telah & 8 \\
dikerjakan & \\
\hline
\end{tabular}

\section{Hasil dan Pembahasan}

Kegiatan pengabdian kepada masyarakat dengan judul implementasi e-book berbasis smartphone pada materi polinomial di kelas XI SMA Negeri 4 Tanjungpinang dilaksanakan via Zoom dan grup Whatsapp Messenger. Implementasi kegiatan PKM melalui tiga rangkaian kegiatan yaitu tahap pemaparan, tahap implementasi e-book dan tahap evaluasi PKM telah tuntas dilaksanakan. Tahap pemaparan penggunaan $e$-book dilakukan secara daring menggunakan zoom yang diakhiri dengan sesi diskusi dan tanya jawab seputar penggunaan $e$-book berbasis smartphone pada materi polinomial. Tahap pemaparan dihadiri oleh 2 orang anggota tim PKM, 20 siswa dan 1 orang guru matematika.

Kegiatan selanjutnya adalah penggunaan e-book berbasis smartphone dalam kegiatan pembelajaran pada materi polinomial kepada siswa kelas XI SMA Negeri 4 Tanjungpinang. Tahap kegiatan ini juga dilakukan dengan bantuan platform zoom meeting. Kegiatan implementasi PKM dihadiri oleh 4 orang anggota tim PKM, 20 orang siswa, dan seorang guru matematika. Pada tahap implementasi $e$-book ini, salah seorang anggota tim PKM bertindak sebagai guru pengajar (Gambar 2).

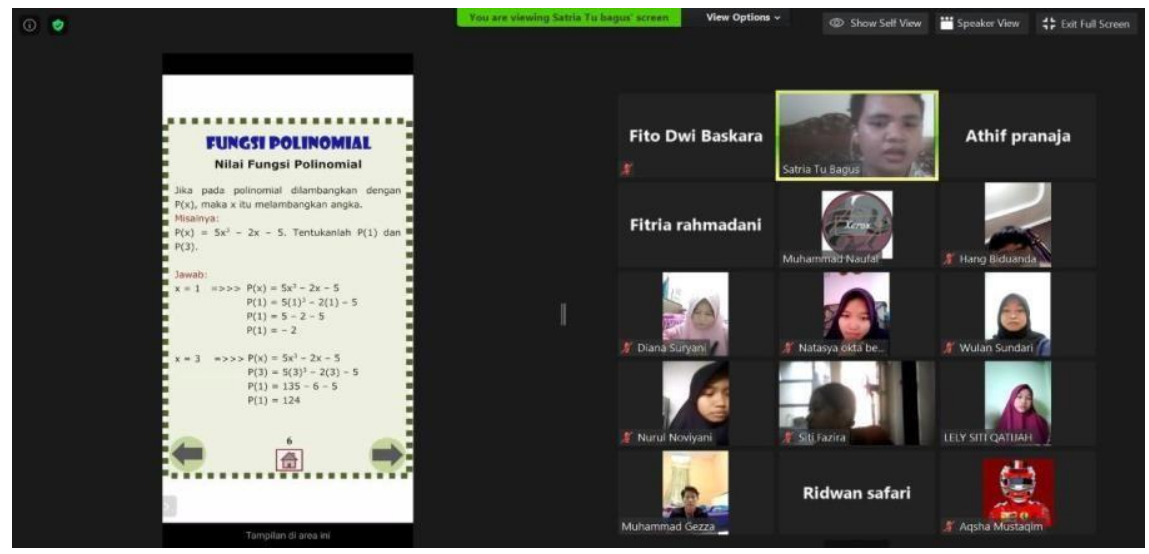

Gambar 2. Tahap implementasi $e$-book

Berbagai keterbatasan pada pelaksanaan pembelajaran jarak jauh (PJJ) daring pada masa pandemi Covid-19 menjadi kendala implementasi e-book berbasis smartphone di SMA Negeri 4 Tanjungpinang. Beberapa kendala yaitu adanya pembatasan durasi pertemuan yang seharusnya 90 menit menjadi 45 menit dan jaringan internet yang kurang stabil. Hal ini berdampak pada pengalaman belajar yang dirasakan oleh siswa menjadi kurang optimal.

Kegiatan akhir implementasi PKM adalah pelaksanaan evaluasi. Evaluasi PKM dilakukan dengan menggunakan menggunakan instrumen angket yang dapat diakses melalui tautan google form. Instrumen angket digunakan untuk menghimpun data respon siswa terhadap impementasi PKM yang telah dilakukan. Instrumen angket terdiri dari 8 (delapan) item yang digunakan untuk mengakses tiga aspek penilaian yaitu desain, usabilitas dan manfaat. Sebelum melakukan pengisian angket, diadakan pertemuan pada platform zoom meeting yang bertujuan untuk memberikan penjelasan tentang tata cara pengisian angket kepada siswa. Tautan google form dibagikan melalui share screen dan kolom chat zoom meeting. Instrumen angket evaluasi 
JURNAL ANUGERAH, November 2020; Vol 2(2): 75 - 82

e-ISSN 2715-8179

diisi oleh 20 siswa kelas XI SMA Negeri 4 Tanjungpinang. Hasil pengisian angket oleh 20 siswa dapat dilihat pada Gambar 3.

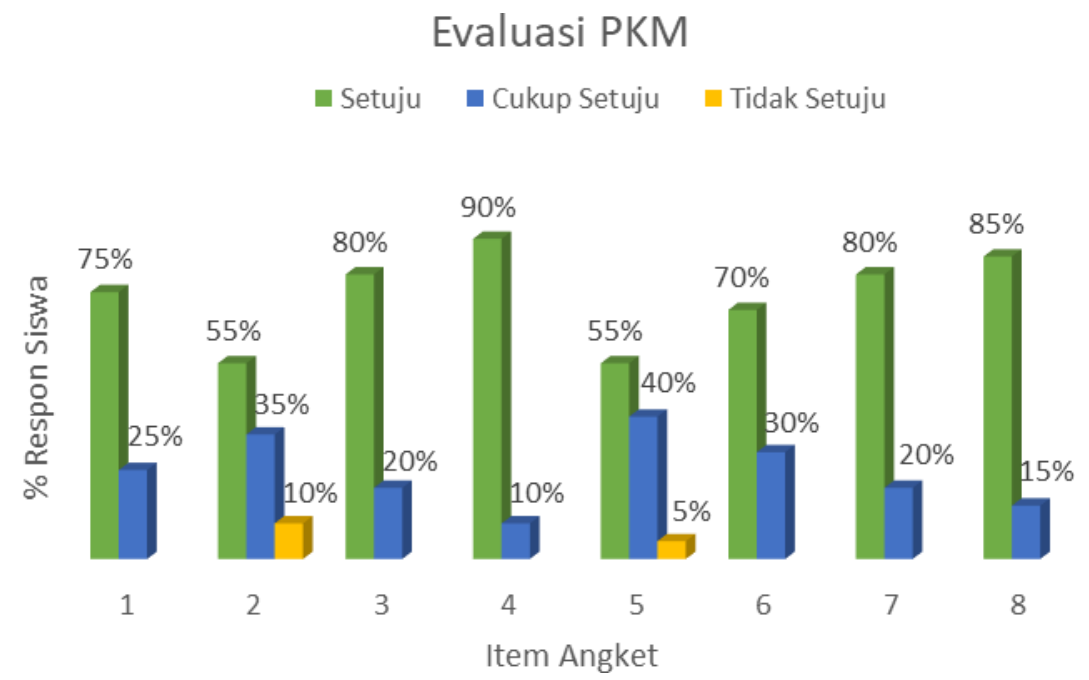

Gambar 3. Data hasil angket evaluasi PKM

Berdasarkan Gambar 3, sebanyak 75\% siswa menilai e-book berbasis smartphone yang dikembangkan menarik bagi siswa. Harackiewicz, Smith, dan Prinski (2016) mengatakan bahwa salah satu upaya menarik minat belajar siswa yaitu dengan menciptakan lingkungan belajar yang dapat menarik perhatian siswa. Siswa kelas IX SMA Negeri Tanjungpinang merupakan generasi milenial yang sangat dekat dengan kemajuan teknologi di bidang komunikasi dan informasi dengan salah satu produk unggulannya yaitu teknologi smartphone. Pengembangan media pembelajaran dengan pemanfaatan teknologi smartphone sama halnya dengan menciptakan media pembelajaran yang dekat dengan objek yang diminati oleh siswa. Akibatnya, suatu hal yang wajr jika $e$-book berbasis smartphone pada materi polinomial yang digunakan dapat menarik perhatian siswa terhadap materi yang disajikan. Siswa juga menilai aspek kepraktisan yang ditawarkan oleh $e$-book berbasis smartphone yaitu dapat dibawa dan digunakan dimana saja (item 3 dan item 4) menjadi keunggulan yang dimiliki oleh $e$-book yang digunakan.

Aktivitas belajar yang menarik bagi siswa dapat meningkatkan perhatian dan partisipasi siswa dalam kegiatan pembelajarn (Harackiewicz et al., 2016; Kahu, Nelson, \& Picton, 2017). Pengalaman belajar yang berkesan bagi siswa berdampak pada peningkatan minat belajar siswa terhadap konten pembelajaran (Kahu et al., 2017). Pengalaman belajar siswa selama implementasi PKM dapat dilihat dari respon siswa terhadap penyataan pada item 3 , item 6 , dan item 8 . Hasil angket menunjukkan bahwa $80 \%$ siswa menyatakan $e$-book dapat digunakan dengan mudah (item 3). Sebanyak $70 \%$ siswa menyatakan e-book berbasis smartphone yang digunakan membantu siswa lebih mudah memahami materi pelajara (item 6). Uraian materi polinomial yang terdapat dalam e-book disesuaikan dengan tingkat perkembangan siswa sehingga lebih mudah dimengerti oleh siswa. Penjelasan materi disajikan secara ringkas, padat dan jelas sehingga dapat memudahkan siswa memahami materi yang disajikan. Lebih lanjut, hasil angket menunjukkan $85 \%$ siswa mengapresiasi adanya umpan balik hasil evaluasi yang dapat segera mereka dapatkan setelah mengerjakan soal evaluasi yang diberikan (item 8). Berdasarkan penjelasan di atas dapat disimpulkan bahwa penggunaan e-book berbasis smartphone pada materi poinomial dalam proses kegiatan belajar mengajar dapat menciptakan pengalaman belajar yang berkesan bagi siswa sehingga dapat menarik minat belajar siswa terhadap konten pembelajaran khususnya pada materi polinomial.

Temuan lain yang dihasilkan berdasarkan hasil angket terkait dampak e-book berbasis smartphone terhadap semangat belajar siswa. Semangat belajar merupakan dorongan belajar yang timbul dari dalam maupun dari luar diri siswa untuk melakukan kegiatan belajar. Sebanyak 55\% siswa menyatakan penggunaan e-book berbasis smartphone sebagai media pembelajaran dapat menambah semangat belajar siswa pada materi polinomial. Hal ini berimplikasi bahwa e-book berbasis smartphone dapat digunakan untuk meningkatkan semangat belajar siswa. Temuan ini didukung oleh hasil penelitian Baby (2019) menyatakan bahwa pemanfaatan perangkat smartphone sebagai media pembelajaran dapat meningkatkan 
partisipasi dan semangat belajar siswa dalam mengikuti berbagai aktivitas pembelajaran di kelas. Hal ini dikarenakan e-book berbasis smartphone dapat memberikan pengalaman belajar yang berbeda dan memberikan tantangan baru bagi siswa.

\section{Kesimpulan}

Kegiatan PKM yang telah dilaksanakan mendapat sambutan yang baik dari pihak sekolah dan siswa kelas XI SMA Negeri 4 Tanjungpinang. Siswa mengapresiasi e-book berbasis smartphone yang digunakan pada kegiatan PKM. Hasil evaluasi menunjukkan penggunaan e-book berbasis smartphone pada kegiatan pembelajaran di kelas dapat menambah minat belajar siswa. Temuan lain yang dihasilkan dalam kegiatan PKM ini adalah penggunaan e-book berbasis smartphone dalam pembelajaran dapat menambah semangat belajar siswa pada materi polinomial. Beberapa kendala yang muncul pada saat implementasi e-book berbasis smartphone adalah terkait kebijakan pembembelajaran jarak jauh (PJJ) daring pada masa pandemi Covid-19 yaitu adanya pembatasan durasi pertemuan yang seharusnya 90 menit menjadi 45 menit dan jaringan internet yang kurang stabil. Hal ini berdampak pada pengalaman belajar yang dialami siswa dengan menggunakan e-book berbasis smartphone menjadi kurang optimal.

\section{Saran}

E-book berbasis smartphone dapat menambah semangat belajar siswa dan membantu memudahkan siswa memahami materi pelajaran. Oleh karena itu, para guru khususnya guru matematika hendaknya mengembangkan e-book berbasis smartphone pada topik materi matematika lainnya dan menggunakannya pada kegiatan pembelajaran untuk membantu kelancaran proses belajar mengajar.

\section{Ucapan Terima Kasih}

Terima kasih kepada kepala sekolah SMA Negeri 4 Tanjungpinang atas kesempatan yang diberikan untuk implementasi kegiatan PKM. Terimakasih juga kepada tim guru SMA Negeri 4 Tanjungpinang dan Prodi Pendidikan Matematika UMRAH atas kerjasama yang baik sehingga terwujudnya implementasi kegiatan PKM ini.

\section{Referensi}

Alwan, M. (2018). Pengembangan multimedia e-book 3d berbasis mobile learning untuk mata pelajaran geografi sma guna mendukung pembelajaran jarak jauh. Jurnal At-Tadbir, 1(2), 26-40.

Asikin, N., Nevrita, N., \& Alpindo, O. (2019). Pelatihan pemanfaatan media pembelajaran berbasis virtual reality untuk guru-guru IPA kota Tanjungpinang. Jurnal Anugerah, 1(2), 71-76.

Astuti, P., \& Febrian. (2019). Diseminasi online multimedia pembelajaran matematika yang dikembangkan menggunakan videoscribe. Jurnal Anugerah, 1(1), 19-24.

Baby, K. T. (2019). Generating internal motivation through mobile application technology. In N. Feza (Ed.), Metacognition in Learning. IntechOpen. https://doi.org/10.5772/intechopen.88346

Choi, S. W., Kim, D. J., Choi, J. S., Ahn, H., Choi, E. J., Song, W. Y., Kim, S., \& Youn, H. (2015). Comparison of risk and protective factors associated with smartphone addiction and internet addiction. Journal of Behavioral Addictions, 4(4), 308-314. https://doi.org/10.1556/2006.4.2015.043

Dwiyogo, W. (2014). Analisis kebutuhan pengembangan model rancangan pembelajaran berbasis blended learning (PBBL) untuk meningkatkan hasil belajar pemecahan masalah. Jurnal Pendidikan Dan Pembelajaran, 21(1).

Harackiewicz, J. M., Smith, J. L., \& Priniski, S. J. (2016). Interest matters: The importance of promoting 
JURNAL ANUGERAH, November 2020; Vol 2(2): 75 - 82

e-ISSN 2715-8179

interest in education. Policy Insights from the Behavioral and Brain Sciences, 3(2), 220-227. https://doi.org/10.1177/2372732216655542

Jazuli, L. O. A., Anggo, M., Rahim, U., \& Sahidin, L. (2017). The application of scientific plus learning to improve mathematics learning achievement of junior high school students grade VII. International Electronic Journal of Mathematics Education, 12(3), 837-844.

Kahu, E., Nelson, K., \& Picton, C. (2017). Student interest as a key driver of engagement for first year students. Student Success, 8(2). https://doi.org/10.5204/ssj.v8i2.379

Nasution, H. N., Nasution, S. W. R., \& Hidayat, T. (2018). Pengembangan media pembelajaran berbasis android mata kuliah aplikasi komputer guna meningkatkan minat belajar mahasiswa. Jurnal Education and Development, 5(1), 8-15. https://doi.org/10.37081/ed.v5i1.363

Negara, H. R. P., Syaharuddin, S., Kurniawati, K. R. A., Mandailina, V., \& Santosa, F. H. (2019). Meningkatkan minat belajar siswa melalui pemanfaatan media belajar berbasis android menggunakan mit app inventor. SELAPARANG Jurnal Pengabdian Masyarakat Berkemajuan, 2(2). https://doi.org/10.31764/jpmb.v2i2.887

Nurhatmi, J., Rusdi, M., \& Kamid, K. (2015). Pengembangan ensiklopedia digital teknologi listrik berbasis contextual teaching and learning (CTL). Edu-Sains: Jurnal Pendidikan Matematika dan Ilmu Pengetahuan Alam, 4(1). https://doi.org/10.22437/jmpmipa.v4i1.2367

Popkova, E. G., Ragulina, Y. V., \& Bogoviz, A. V. (2019). Industry 4.0: Industrial revolution of the 21st century. Springer https://doi.org/10.1007/978-3-319-94310-7

Rosiska, E. (2019). Pemanfaatan aplikasi virtual learning berbasis android dalam meningkatkan kualitas pembelajaran. Jurnal Pengabdian Barelang, 1(1). https://doi.org/10.33884/jpb.v1i01.979

Sam'ani, S., Sutami, S., \& Qamaruzzaman, M. H. (2019). Implementasi aplikasi pembelajaran untuk anak berbasis android. Martabe: Jurnal Pengabdian Kepada Masyarakat, 2(2). https://doi.org/10.31604/jpm.v2i2.106-110

Suartama, I. K., Setyosari, P., Sulthoni, \& Ulfa, S. (2019). Development of an instructional design model for mobile blended learning in higher education. International Journal of Emerging Technologies in Learning, 14(16). https://doi.org/10.3991/ijet.v14i16.10633 